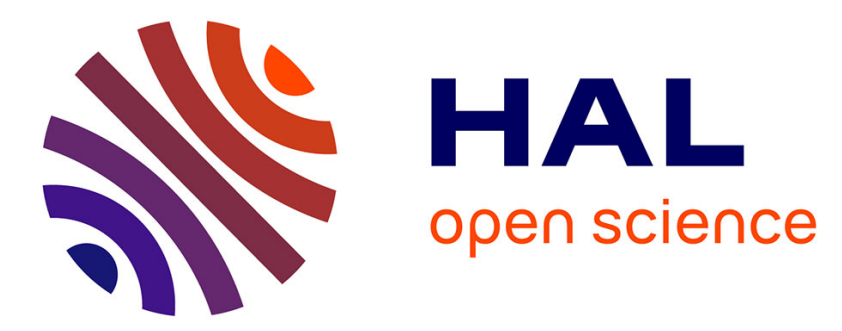

\title{
Integrated Solar-Assisted Heat Pumps for water heating coupled to gas burners; Control criteria for dynamic operation
}

\author{
F. Scarpa, L.A. Tagliafico, G. Tagliafico
}

\section{- To cite this version:}

F. Scarpa, L.A. Tagliafico, G. Tagliafico. Integrated Solar-Assisted Heat Pumps for water heating coupled to gas burners; Control criteria for dynamic operation. Applied Thermal Engineering, 2010, 31 (1), pp.59. 10.1016/j.applthermaleng.2010.08.012 . hal-00685786

\section{HAL Id: hal-00685786 \\ https://hal.science/hal-00685786}

Submitted on 6 Apr 2012

HAL is a multi-disciplinary open access archive for the deposit and dissemination of scientific research documents, whether they are published or not. The documents may come from teaching and research institutions in France or abroad, or from public or private research centers.
L'archive ouverte pluridisciplinaire HAL, est destinée au dépôt et à la diffusion de documents scientifiques de niveau recherche, publiés ou non, émanant des établissements d'enseignement et de recherche français ou étrangers, des laboratoires publics ou privés. 


\section{Accepted Manuscript}

Title: Integrated Solar-Assisted Heat Pumps for water heating coupled to gas burners;

Control criteria for dynamic operation

Authors: F. Scarpa, L.A. Tagliafico, G. Tagliafico

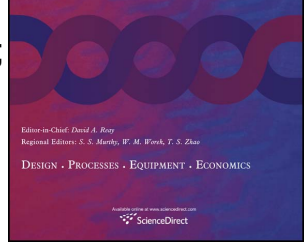

PII:

S1359-4311(10)00339-X

DOI:

10.1016/j.applthermaleng.2010.08.012

Reference: $\quad$ ATE 3205

To appear in: Applied Thermal Engineering

Received Date: 18 January 2010

Revised Date: 26 July 2010

Accepted Date: 11 August 2010

Please cite this article as: F. Scarpa, L.A. Tagliafico, G. Tagliafico. Integrated Solar-Assisted Heat Pumps for water heating coupled to gas burners; Control criteria for dynamic operation, Applied Thermal Engineering (2010), doi: 10.1016/j.applthermaleng.2010.08.012

This is a PDF file of an unedited manuscript that has been accepted for publication. As a service to our customers we are providing this early version of the manuscript. The manuscript will undergo copyediting, typesetting, and review of the resulting proof before it is published in its final form. Please note that during the production process errors may be discovered which could affect the content, and all legal disclaimers that apply to the journal pertain. 


\title{
Integrated Solar-Assisted Heat Pumps for water heating coupled to gas burners; control criteria for dynamic operation
}

Scarpa, F.*, Tagliafico, L.A. and Tagliafico, G.

University of Genoa - DIPTEM/TEC

Division of Thermal Energy and Environmental Conditioning

Via All'Opera Pia 15 A - (I) 16145 Genoa - Italy

(*)Corresponding author: fscarpa@ditec.unige.it

\begin{abstract}
A direct expansion integrated solar assisted heat pump (ISAHP) is compared to a traditional flat plate solar panel for low temperature $\left(45^{\circ} \mathrm{C}\right)$ water heating applications. The (simulated) comparison is accomplished assuming both the devices are energy supplemented with an auxiliary standard gas burner, to provide the typical heat duty of a four-member family. Literature dynamical models of the systems involved have been used to calculate the main performance figures in a context of actual climatic conditions and typical stochastic user demand.

The paper highlights new heat pump control concepts, needed when maximum energy savings are the main goal of the apparatus for given user demand. Simulations confirm the high collector efficiency of the ISAHP when its panel/evaporator works at temperature close to the ambient one. The device, with respect to a flat plate solar water heater, shows a doubled performance, so that it can do the same task just using an unglazed panel with roughly half of the surface.
\end{abstract}

Keywords: Solar assisted; Renewable energy; Heat pump; Direct expansion; Water heater 


\begin{tabular}{|c|c|c|c|c|c|}
\hline & \\
\hline \multicolumn{6}{|c|}{ A heat transfer area (panel/evap.), } \\
\hline \multirow{2}{*}{$\mathrm{COP}$} & coeff. of performance of the cycle & & out & out of the condenser & \\
\hline & total solar irradiation, & $\mathrm{Wm}^{-2}$ & $\mathrm{f}$ & fluid & \\
\hline $\mathrm{h}$ & fluid specific enthalpy, & $\mathrm{J} \mathrm{kg}^{-1}$ & p, pan & panel & \\
\hline $\mathrm{k}$ & thermal conductivity & $\mathrm{Wm}^{-1} \mathrm{~K}^{-1}$ & spe & saved primary energy & \\
\hline KA & thermal conductance, & $\mathrm{W} \mathrm{K}^{-1}$ & $\mathrm{r}$ & refrigerant & \\
\hline M & mass, & $\mathrm{kg}$ & stg & storage tank, reservoir & \\
\hline Mc & thermal capacity, & $\mathrm{J} \mathrm{K}^{-1}$ & $\mathrm{~s}$ & storage & \\
\hline$\dot{m}$ & mass flow rate, & $\mathrm{kg} \mathrm{s}^{-1}$ & tap & tap water & \\
\hline $\mathrm{p}$ & pressure, & $\mathrm{Pa}$ & $\mathrm{u}$ & user & \\
\hline $\mathrm{Pc}$ & compressor power, & $\mathrm{W}$ & $\mathrm{v}$ & volumetric & \\
\hline q & heat transfer rate, & $\mathrm{W}$ & 1 & evaporator exit & \\
\hline $\mathrm{s}$ & thickness of insulating material, & $\mathrm{m}$ & 2 & compressor exit & \\
\hline $\mathrm{T}$ & temperature, & K & $2 \mathrm{id}$ & compressor exit (isentropic) & \\
\hline \multirow[t]{2}{*}{$\mathrm{v}$} & specific volume, & $\mathrm{m}^{3} \mathrm{~kg}^{-1}$ & 3 & condenser exit & \\
\hline & & & 4 & expansion valve exit & \\
\hline \multicolumn{3}{|c|}{ Subscripts } & \multicolumn{3}{|c|}{ Greek symbols } \\
\hline \multirow{2}{*}{$\begin{array}{l}\text { aux } \\
\text { burn }\end{array}$} & auxiliary & & $\alpha$ & absorptivity (solar wavelengths), & \\
\hline & burner & & $\varepsilon$ & emissivity (infrared), & \\
\hline $\mathrm{c}$ & compressor & & $\eta$ & efficiency, & \\
\hline cond & from the condensing fluid & & $\tau$ & time, & $\mathrm{s}$ \\
\hline $\mathrm{d}$ & lost from the storage tank & & $\omega$ & rotation speed, & $\mathrm{rpm}$ \\
\hline evap & to the evaporating fluid & & $\xi$ & performance parameter & \\
\hline $\mathrm{e}$ & of the ambient (environmental) & & & & \\
\hline el & electric & & & & \\
\hline free & for free & & & & \\
\hline
\end{tabular}




\section{Introduction}

A strong innovation is needed in energy production technologies in order to make renewable energy resources affordable and competitive with traditional ones and to adhere to the lines settled by the Kyoto protocol [1] and subsequent international agreements. In the last years, many improvements have been carried out in the field of air conditioning, heating and refrigeration, thanks to the spreading of heat pump systems, generally reversible, that allow water heating and air heating or cooling to be performed with a significant energy saving with respect to traditional electrical and gas systems [2,3]. Scientific research is being concentrated in the development and improvement of these technologies, integrating them with other ones (sea water heat exchangers, geothermal pipes, absorption systems).

On the side of solar heaters, several applications are available in the field of low-temperature (around $45^{\circ} \mathrm{C}$ ) water heaters, while some developments are envisaged in the field of solar absorption cooling plants [4] and solar assisted heat pumps (SAHP). These last can use traditional solar panels to pre-heat a water tank to be coupled to electrical heat pumps [5], also with intermediate energy storage [6,7], or gas burners [8] or absorption systems [9,10]. Some industrial attempts are now available on the market [11].

A possible alternative to exploit at best the available solar radiation is to directly use solar panels as evaporators in a vapor compression heat pump cycle. Recently, the use of fine-tuned control techniques in order to obtain "optimal performance" from a system is quickly diffusing also in the field of vapor compression refrigeration technology [12], thus matching the need for continuous regulation asked by these modern devices [13].

Also for this reason there is a growing interest around ISAHP (Integrated Solar Assisted Heat Pump) technology. We use the term ISAHP to specify that the traditional vapor compression heat pump is integrated into a solar panel, directly used as the evaporator of the system. These systems are also known as "direct expansion solar assisted heat pumps" or DX-SAHP.

Various studies on ISAHP models are available. Some of them, e.g. [13], refers to variable speed compressors, others $[14,15]$ propose the simpler household refrigeration technology to be used as the heat pump system. For the variable capacity compressors configuration different fluids are being tried [16].

The aim of this work, once a proper dynamic model for the ISAHP is developed and tuned, is to analyze its performance and compare it to a traditional thermal solar panel (TSP) under variable climatic conditions and typical stochastic user demand. The comparison is made using an ISAHP bare solar panel 
with half the active surface area than that of the one of the TSP device (indeed preliminary tests revealed a great increase of the ISAHP plate collector efficiency due to its lower working temperature).

Performances are analyzed using actual weather conditions (environmental temperature and solar radiation) occurred in Genoa, Italy, during the year 2004. A stochastic model of water variable consumption (sanitary water) has been provided as well, in order to make the dynamic boundary conditions of the systems as realistic as possible.

\section{Basic ISAHP assembly}

Figure 1 shows the simplified schematic of the traditional thermal solar panel(TSP) plant, Fig.1A, and its evolution, the ISAHP, Fig.1B. The basic function is the production of sanitary water at the desired temperature (e.g. $45^{\circ} \mathrm{C}$ ), using also some thermal energy by means of an auxiliary burner, when needed. The two drawings are practically equal except for the presence of the compressor and the expansion valve in the ISAHP system, which obviously operates with a proper refrigerant fluid. In the traditional panel the temperature $T_{\mathrm{pan}}$ of the irradiated plate is, during the active phase, higher than the temperature $T_{\text {stg }}$ of the water contained in the storage tank. As a consequence, a great amount of energy is wasted to the surroundings by means of both radiation and convection. On the other hand, in the innovative device the compressor (along with the expansion valve) allows a definite temperature difference between the plate and the heat exchanger (a condenser) to be held. In this way the panel can be maintained near the thermal equilibrium with the surroundings, and heat transfer losses are minimized. Furthermore, the panel structure is simplified down to a bare flat metal plate since nor glass cover nor expensive vacuum solutions are any more required to decrease convection and irradiation losses.

Another advantage of the ISAHP is its potential ability to deliver useful thermal power also during the night and in the cold months, performance that is precluded to traditional TSP.

Since the panel temperature is also a function of solar radiation $G$, and this last is variable during the day, a Variable Capacity Compressor (VCC) is needed to take out at any time the right heat rate from the panel, thus keeping $T_{\text {pan }}$ near the environmental one. More sophisticated control techniques, with respect to the brute on-off regulation, are therefore required to manage the process complexity of this innovative system during operation. 


\section{Device models}

The formulation of the dynamic model for refrigeration devices presented in [17] has been adapted to the ISAHP. The scheme of Figure 2(A) focuses on the relevant energy transfer rates occurring in the ISAHP device:

- $\quad q_{\text {in }}$ : thermal power from the surroundings to the solar panel (solar irradiation and other convective heat transfers);

- $\quad q_{\text {evap }}$ : the heat transferred to the operating fluid, equal to $q_{\text {in }}$ in steady state conditions;

- $\quad q_{\text {cond }}$ : thermal power from the operating fluid to the condenser solid body, equal to $q_{\text {out }}$ in steady state conditions;

- $q_{\text {out }}$ thermal power to the water reservoir.

- $\quad q_{\text {stg }}$ : heat delivered from the storage tank, based on user demand. It is supplemented by $q_{\text {aux }}$ in an instantaneous gas burner if water temperature in the reservoir is less than $45{ }^{\circ} \mathrm{C}$. Otherwise $\left(T_{\text {stg }}>45^{\circ} \mathrm{C}\right)$ a proper mixing with tap water occurs.

- $\quad q_{\mathrm{d}}$ : thermal power wasted to the surroundings trough the tank walls.

- $\quad q_{\mathrm{u}}$ : user request.

The model is based on a simplified lumped description of a system operating along an inverse cycle. The cycle works between thermal sources with finite thermal capacities as shown in Figure 2(A), the external power, Pc, being provided by means of a VCC. The approach just accounts for the differential equations governing the time-temperature history of the different devices involving heat transfer (with the refrigerant fluid and with the outside) while neglecting the dynamics of physical phenomena having time constants below a few minutes. The general validity of this approach was proven experimentally in [17] and briefly reported as Appendix.

The model of the traditional solar plant, TSP, is very close to the ISAHP one. The inverse cycle is replaced by a water circulation loop operated by a hydraulic pump, working between two finite thermal capacity sources (the solar panel and the water storage tank). In the other parts and components of the plant (storage tank and gas burner) the same equations of the ISAHP model were used.

Usual forced convection heat transfer calculations have been performed for the water loop, (instead of ISAHP condenser and evaporator sections), including them in the dynamic TSP system analysis. 
The TSP solar panel is conceived as a thin absorber sheet $\left(4 \mathrm{~m}^{2}\right.$ active surface $)$ to which a selective coating is applied. As usual for TSP, coil tubes are placed in an insulated casing with a glass cover for reducing convection and irradiation heat losses. The calculated pump power consumption for water circulation $\left(\mathrm{m}_{\mathrm{H} 2 \mathrm{O}}=120 \mathrm{~kg} \cdot \mathrm{h}^{-1}\right)$ resulted to be negligible.

Concerning the collector efficiencies, both the unglazed active surface $\left(2 \mathrm{~m}^{2}\right)$ of the ISAHP and the single glazed one of the TSP are characterized by efficiency curves comparable to data available in literature [20]. All the operating and geometrical data used in the calculation are available in Table 1.

The resulting set of differential dynamic equations where solved by means of standard software packages [21]. 


\section{Working conditions}

Simulations were performed using, over a period of one year, actual climatic conditions (environmental temperature and solar radiation) occurred in Genoa in the year 2004 according to [22]. Figure 3 shows, as an example, the environmental temperature and the solar radiation during October.

A four-member typical family has been selected as "the user" and the behavior of the ISAHP and the other TSP device has been investigated regarding their ability to deliver about 250 1/day of sanitary water (e.g., about 4 showers) with a temperature of $45{ }^{\circ} \mathrm{C}$. The energy saving for both systems, the ISAHP and the TSP, is calculated with respect to an instantaneous gas burner (combustion efficiency 0.87), which has been assumed as a reference. The same burner is also employed for energy integration purposes in both the solar heating setups.

The systems include a 300 liters water storage tank and are controlled by means of very simple operating criteria. The pump of the TSP is "on" only when the water temperature in the panel is higher than that in the tank $\left(T_{\text {pan }}>T_{\text {stg }}\right)$ but lower than an imposed maximum temperature of $90{ }^{\circ} \mathrm{C}$. Temperature dead bands of $3{ }^{\circ} \mathrm{C}, \Delta T_{\mathrm{L}}$, and $10^{\circ} \mathrm{C}, \Delta T_{\mathrm{H}}$, for the lower and the higher set points respectively have been implemented. The ISAHP device, instead, employs a variable capacity compressor and its power is controlled in open loop, making it nearly proportional to the solar incident radiation. In this case, a time dead band of 15 minutes has been adopted to avoid frequent on/off switches (e.g., rapid passage of clouds) to provide reliable operation for long time. Again, the maximum temperature in the storage tank has been limited as in the TSP device for safety reasons.

When the water at the outlet of the storage tank has a temperature lower than $45{ }^{\circ} \mathrm{C}$, an instantaneous gas burner is used as extra energy supplier. On the other hand, when the water from the storage tank has a temperature exceeding $45^{\circ} \mathrm{C}$, a proper mixing with cold tap water is assumed (see Table 2 for the values of $\left.T_{\text {tap }}\right)$.

Due to our regulation choice the temperature of the panel is always greater than that of the surroundings, thus condensation phenomena are unlikely to happen and were not considered in the simulation.

The user load is represented by approximately $250 \mathrm{l} /$ day of $45^{\circ} \mathrm{C}$ water (i.e. around $1000 \mathrm{MJ} / \mathrm{month}$ ). We simulate this load as a stochastic process that behaves like a typical family making random use of sanitary water for hygienic purposes, e.g. to have a shower. The use of this approach has to be 
emphasized since it provides results different from those coming out of standard "duty cycle load" methods (e.g., [23]).

The "one shower process" works as follows: a couple of random numbers representing time intervals are drawn from two different uniform distributions. The first number is in the range from 2 up to 9 minutes and represents the shower duration. The second number is the time gap between two showers. It is in the range 0 - 9 hours between 2:00 and 22:00 o'clock and in the range $0-24$ hours otherwise. With these values the water request history appears to follow a realistic behavior and the global energy demand approaches quite well the total value of $1000 \mathrm{MJ}$ for one month.

Due to the stochastic nature of the simulation, proper confidence bounds must be added to each numeric result. We make this in a MonteCarlo fashion, calculating the sample mean and variance from various (100 runs) simulated experiments and then reporting the 95\% confidence bounds of all the calculated parameters. 


\section{Performance indicators}

In what follows the definitions of the main figures of merit used to quantify and compare the performance of the investigated devices are reported. To take into account the random mechanism applied to simulate the user demand and the variations of the environmental conditions (solar irradiation, temperature, clouds, and so on) energy data were calculated from integration over a time period of one month.

Coefficient of performance of the thermodynamic cycle (Heat Pump mode)

$$
C O P=\int_{\text {month }} q_{\text {cond }} d \tau \cdot\left(\int_{\text {month }} P_{c} d \tau\right)^{-1}
$$

It is the mean COP of the inverse cycle, based on monthly energy balances.

Second law efficiency (HP subsystem)

The ratio between the work spent a Carnot inverse machine and the one spent by the actual heat pump subsystem, when operated between the same thermal sources and with the same instantaneous thermal transfer toward the storage tank;

$$
\eta_{I I}=\int_{\text {month }} q_{\text {cond }}\left(1-\frac{T_{\text {pan }}}{T_{\text {stg }}}\right) d \tau \cdot\left(\int_{\text {month }} P_{c} d \tau\right)^{-1}
$$

\section{Exergetic efficiency (HP subsystem)}

The ratio between the desired exergy transfer and the exergy input to the HP [24].

$$
\eta_{E x}=\int_{\text {month }}\left[q_{\text {cond }}\left(1-\frac{T_{e}}{T_{\text {stg }}}\right)+q_{\text {evap }}\left(1-\frac{T_{e}}{T_{\text {pan }}}\right)\right] d \tau \cdot\left(\int_{\text {month }} P_{c} d \tau\right)^{-1} \quad T[\mathrm{~K}]
$$

It will coincide with the previous index when $T_{p a n}=T_{e}$

\section{Solar panel efficiency}

It is the ratio between the energy entering the solar collector (the evaporator for the ISAHP) and the incident irradiated energy; 


$$
\eta_{\text {pan }}=\int_{\text {month }} q_{i n} d \tau \cdot\left(\int_{\text {month }} G A d \tau\right)^{-1}
$$

\section{Renewable energy exploitation parameters}

Applying, at steady state, global first law energy balance to the system of Figure 2, several energy flow rates can be observed and the corresponding performance parameters defined (in what follows all thermal and mechanical powers are considered positive for a simpler reading). Since

$$
q_{u}=q_{\text {in }}+P_{c}-q_{d}+q_{\text {aux }}
$$

the energy used "for free" since coming from renewable sources (not only solar, if ISAHP operates also when $T_{\mathrm{pan}}<T_{\mathrm{e}}$ ) will be:

$$
q_{\text {free }}=q_{u}-q_{\text {aux }}-P_{c}=q_{\text {in }}-q_{d}
$$

These relations should be better used on time-integrated, energy-based mean values, referred to reasonable long time periods, so we introduce the following;

\section{"for free" fraction}

The ratio between free (from the environment) and useful user energy:

$$
\xi_{\text {free }}=\int_{\text {month }} q_{\text {free }} d \tau \cdot\left(\int_{\text {month }} q_{u} d \tau\right)^{-1}
$$

(it is similar to solar fraction); 


\section{Energy fraction for the Compressor}

The ratio between compressor energy consumption and useful thermal energy for the user

$$
\xi_{\text {comp }}=\int_{\text {month }} P_{c} d \tau \cdot\left(\int_{\text {month }} q_{u} d \tau\right)^{-1}
$$

Saved Primary Energy index

It makes a comparison between the actual consumption of primary energy resources and the one needed in the case of gas burner alone (assumed as a reference)

$$
\xi_{\text {spe }}=\frac{E_{p_{-} \text {gas }}-E_{p_{-} I S A H P}}{E_{p_{-} \text {gas }}}=1-\frac{\int_{\text {month }}\left(q_{\text {aux }}+P_{c} \cdot \eta_{\text {burn }} / \eta_{e l}\right) d \tau}{\int_{\text {monht }} q_{u} d \tau}
$$

where some suitable values for the combustion efficiency $\eta_{\text {burn }}$ of the burner and of the conversion efficiency from primary-to-electric energy, $\eta_{\mathrm{el}}$, is to be assumed. In the present paper the conventional values $\eta_{\text {burn }}=0.87$ [25] and $\eta_{\mathrm{el}}=0.36$ have been assumed, this last being the global average conversion efficiency for all fossil fuels [26]. For the TSP the saved primary energy index and the "for free" index will have the same numerical values. Concerning ISAHP, the index defined in Eq. (11) also gives information about actual money saving, since the ratio between the two conversion efficiency parameters, $\eta_{e l} / \eta_{b u r n}$, has similar values (at least in Italy) to the ratio between the final prices of gas and electric energy in end uses.

\section{Tuning of the control strategy}

As said, a variable capacity compressor is employed to better fit the variability of the weather conditions. In particular the supplied power is made roughly proportional to the solar incident radiation. The right proportionality factor has been chosen according to a preliminary analysis of the relationship between Saved Primary Energy index, $\xi_{s p e}$, values and COP values during four representative months as depicted in Figure 4.

It is confirmed that there is no advantage (from the primary energy saving point of view) in operating the system at COP values lower than 3, since all that is gained from environmental (free) sources is duly paid in terms of compressor electric energy consumption. The value of this operative constrain is well known 
and can be inferred, in a roughly way, also from Eq. 7. Neglecting thermal dispersions from the water storage and in steady state conditions, it emerges that COP has to be greater than $\eta_{\text {burn }} / \eta_{e l}$ (2.4 in this study) to provide useful operations, i.e. $\xi_{s p e}>0$, in respect to those of a gas burner alone. On the other side, the abrupt decline of the curves when $\mathrm{COP}>20$ has to be ascribed to the lack of control ability of the compressor below $1600 \mathrm{rpm}$, and to the utilized time dead bands to avoid compressor damages.

For all the months, excluding July, a maximum of the COP is found for values around 7. In any case the maximum shape is rather flat giving us some flexibility in the final choice to be implemented in the control algorithm. Higher COP values mean lower average compressor speed with some issues about lubrication and bearing reliability, therefore it appears reasonable to tune the control law to always maintain the $\mathrm{COP}$ at values around 8 . In this way we give up edge performances in favor of greater system reliability.

\section{Results and discussion}

For the sake of simplicity, all the parameters are presented only with reference to four different representative months; January, April, July and October. Table 2 shows the performance of the devices using the defined indices, along with their confidence bounds, plus a few integral quantities.

Month by month, the main average weather conditions (external temperature, irradiation power, rain time fraction) are given along with the user load info, such as the monthly energy consumption, the average daily water demand and the temperature of the cold tap water. Also the time averaged (over one month) temperatures of the panel and of the stored water are given, differentiating between global averages and averages taken only during active working periods, i.e. with running compressor/pump. These last are meaningful in the characterization of the average working point of the devices. To avoid the risk of an oversimplified model, we include in the analysis the monitoring of second law efficiencies as defined in Eq. 4 and 5. Table 2 puts in evidence values of $\eta_{I I}$ and $\eta_{E x}$ around 0.35 , typical for this kind of systems, thus confirming the model is able to keep the main characteristics of "real world" devices.

Figure 5 shows instantaneous collector efficiency, $\eta_{p a n}$, values sampled during the simulation along with reference literature curves. The reported values correspond to an arbitrary day of July for both ISAHP and TSP. Dashed lines refer to the assumed reference [20]. On this side, Table 2 shows a clear supremacy of 
the ISAHP with averaged values of $\eta_{p a n}$ in the order $0.6-0.8$ against a value of 0.3 for the traditional panel. This confirms ISAHP ability to keep the panel temperature low, in order to reduce heat losses toward the surroundings, thus achieving high collector efficiency. In the introduction we stressed how this ISAHP feature corroborate the choice to utilize a strongly reduced active surface comparing different devices (ISAHP and TSP) able to satisfy the same user request.

Among the various performance parameters introduced in the previous paragraph, we focus our attention on the saved primary energy index, $\xi_{\text {spe }}$, and on the free energy index, $\xi_{\text {free }}$. They are reported, for convenience, also in Figure 6. As expected, despite the halved surface, the ISAHP assures about the same performance than the TSP. In particular it offers better performance in the cold months, during which the need of thermal power is usually more important. Only in July the TSP shows a better value for both $\xi_{\text {spe }}$ ( 0.81 versus 0.63 of the ISAHP) and $\xi_{\text {free }}(0.81$ versus 0.80 of the ISAHP).

Averaging data over a year basis, it results for the TSP : $\bar{\xi}_{\text {free }} \equiv \bar{\xi}_{\text {spe }}=0.48$ while the ISAHP shows $\bar{\xi}_{\text {free }}=0.56$ and $\bar{\xi}_{\text {spe }}=0.44$. So, the ISAHP maintains the promise to deliver about the same useful heat power of the TSP using just half of the active solar panel surface. Moreover, it uses a simpler and less expensive structure: Table 1 reports the innovative panel featuring a weight of $18 \mathrm{~kg}$ against $80 \mathrm{~kg}$ of the traditional one (ordinary production of a big Italian manufacturer). As a consequence also the installation is simplified with an additional cost decrease.

The obtained values of COP need some comments since they appear, at a glance, too much high (around 8), especially if we consider that these are average values, not peak ones. Ordinary air and water heat pumps exhibit COP values some how in the range 2.5-4.5 and, generally speaking, we are unfamiliar with values greater than 5 when dealing with inverse cycles, irrespective of their nature. Nevertheless, opposite to traditional heat pumps, ISAHP evaporator temperature is not linked to the ambient one and the opportunity to increase the panel temperature to minimize compressor work has to be exploited as suggested by the simulation results.

However, literature data about solar heat pumps does not seem to confirm this operative choice, and COP values beyond 7 [27] are rarely found. In our opinion this is probably due to the control criterion often adopted for these systems, which asks for the collector temperature to be maintained near or below the environmental one. Many Authors indeed, e.g. [28,29], stress the feature of collecting energy not only 
from solar irradiation but also from the environment and ambient air (including humidity condensation). Although this characteristic of the solar assisted heat pumps is one of the key points with respect to TSP, it has to be exploited during night or, anyway, only in case of low solar irradiation, since it belongs to system flexibility rather than to system "performance". As a consequence the results of this study strongly suggest that the right balance for a good "performance" is towards low compressor energy consumption, rather than low collector thermal losses.

The main reason for this apparent discrepancy is due to the kind of investigation made in this study, which refers to the tuning and test of the system when external gas burner device is used for thermal aid, rather than using an electric boosted one [28] or a standalone system [30]. It seems reasonable that in a different operative context optimal performance is achieved by means of different working set points.

If we had for instance replaced the gas burner used in the present ISAHP device by means of an instantaneous electrical heater, hypothetically able to deliver the same thermal power of the gas burner, we could assume $\eta_{\text {burn }}=\eta_{e l}=0.36$ to convert auxiliary energy into primary energy consumption. In such a case, $\xi_{\text {spe }}=\xi_{\text {free }}$. So, to maximize primary saved energy we have to maximize $q_{i n}$, the power collected by the panel, and this is accomplished by means of low collector temperature both to increase collector efficiency and to draw energy also from the environment $\left(T_{p a n}<T_{e}\right)$. This working condition, which requires to increase $q_{\text {in }}$ against $q_{\text {aux }}$, also causes high storage temperatures, driving toward low COP values as a preferable choice. A very different picture, compared to our gas burner configuration.

We conclude by noting another positive feature of the ISAHP device, i.e. its small electric power consumption. Indeed, owing to the high values of COP, the compressor energy fraction is, on average, around $10 \%$ of the total useful energy delivered to the user. The combined use of photovoltaic devices, along with electric energy storage, appears thus feasible even when electric power sources are not available. This is, in our opinion, an important issue for future studies.

\section{Duty cycles vs. stochastic loads}

It frequently happens in current practice that standard duty load cycles, e.g. [31], are used to measure or estimate conventional solar panel performance, with measuring techniques well consolidated mainly for steady state at nearly optimal operating conditions. 
So, significant differences arise between actual data collected during the operating life of the apparatus and expected parameters based on standard duty load cycles. Usually in a duty cycle the interval between water usages are well and regularly spaced, so that the storage tank has enough time to receive energy from the solar panel system, that is to recharge itself. On the contrary, user requests are not so well placed in the real world. It happens, for instance, that two persons have their showers consecutively, with no or little time gap in between. In this case the reservoir temperature will drop down and the gas burner shall supply more energy, with a worsening of both $\xi_{\text {free }}$ and $\xi_{\text {spe }}$. An increase of the storage tank size is only of limited usefulness and this is not surprising since a standard load of $0.2 \mathrm{~kg} / \mathrm{s}$ of $45^{\circ} \mathrm{C}$ hot water represents a thermal power of about $25 \mathrm{~kW}\left(T_{\text {tap }}=15^{\circ} \mathrm{C}\right)$.

To better quantify this concept the simulations were repeated using a deterministic load, that is assuming the duration of a shower to be always equal to 5.5 minutes and the wait time fixed at 4.5 or 12 hours (daytime and night-time respectively). In other words, we substitute the function RND in the programmed stochastic process with its average value, that is 0.5. The results reported in Table 3 show an overestimation of both $\xi_{\text {free }}$ and $\xi_{\text {spe }}$ in respect of the results previously described. This behavior is particularly marked during July, where differences of about $5 \div 10 \%$ can be noted. This kind of results, worth of further study, rises some doubts about the use of standardized hot water consumption pattern load such as the aforementioned ISO 9459-3, as reported in [32]. In the authors' opinion such load profiles can be used only as a starting point for the design and construction of solar panel systems, while more realistic stochastic loads are needed to develop detailed analyses and optimized control strategies, especially when multi-control multi-variable systems like ISAHP are involved.

\section{Conclusions}

Two contending devices have been modeled and tested in a simulated environment, which provides realistic energy demand of a four-member family and whether conditions representative of temperate climates. From these tests several performance parameters have been calculated assuming as a reference the standard instantaneous gas burner solution. 
The considered devices are an integrated direct expansion solar assisted heat pump (ISAHP, $2 \mathrm{~m}^{2}$ ) and a traditional flat plate collector solar assembly $\left(\mathrm{TSP}, 4 \mathrm{~m}^{2}\right.$ ). They are both boosted by means of an auxiliary gas burner in order to assure the needed heat duty $\left(45^{\circ} \mathrm{C}\right.$ hot water).

The results show that the ISAHP plant can replace the traditional solar water heater using only around half of its active collector surface. Furthermore, since the ISAHP panel can be maintained at a temperature nearer the environmental one, it can be used simply bare, without the pricey technologies (glass cover, insulation, vacuum, etc.) commonly used to minimize the heat losses of a TSP. The innovative solar panel configuration is therefore lighter and definitely less expensive than the traditional one, also from the installation cost point of view.

The required electric energy is very small, so that ISAHP configurations can be envisaged with an integrated photovoltaic surface able to operate, like the natural circulation TSP, also in absence of electric energy supply.

To obtain the reported results a variable capacity compressor is needed and the necessity to operate at high COP value is emerged. High COP values were obtained with low compressor speed, thus increasing the risk for lubrication related problems. However high panel temperatures are needed to fully exploit the energy potential of solar assisted heat pumps. In other words, the key is toward low compressor energy consumption, rather than low thermal losses of the solar collector.

This conclusion is valid only when a gas burner is assumed as a reference heat source and boosting device; different operating conditions (and conclusions) should follow if electrical water heaters were assumed as reference heating means and boosting devices.

The ISAHP has shown its ability to thermally decouple the solar collector from the storage tank with low electric power consumption, thus encouraging the studies towards higher temperature applications $\left(60{ }^{\circ} \mathrm{C}\right.$ for heating purposes or even $80{ }^{\circ} \mathrm{C}$ for cooling systems coupled to absorption refrigerators). Finally, the low compressor energy fraction drives to further studies in the field of combined use of photovoltaic devices, along with electric energy storage, thus opening for ISAHP applications were electric power sources are not available. 


\section{Acknowledgements}

The present work was supported by Genuense Atheneum.

\section{References}

[1] Kyoto Protocol to the United Nations Framework Convention on Climatic Change. English Conference of the Parties, third session, Kyoto, Japan 1-10 December1997.

[2] De Swardt C.A., Meyer J. P. A performance comparison between an air-source and a ground-source reversible heat pump, International Journal of Energy Research 2001, 25, 10, pp. 899-910. DOI:10.1002/er.730.

[3] Sarkar J., Souvik Bhattacharyya, M. Ram Gopal. Transcritical $\mathrm{CO}_{2}$ heat pump systems: exergy analysis including heat transfer and fluid flow effects, Energy Conversion and Management 2006, 46, pp. 2053-2067. DOI: 10.1016/S0140-7007(01)00021-4.

[4] Garcia-Casals X. Solar Absorption cooling in Spain: Perspectives and outcomes from the simulation of recent installations, Renewable Energy, 31, 2001, pp. 1371-1389. DOI:10.1016/j.renene.2005.07.002.

[5] Yumrutas R., Kaska Ö. Experimental investigation of thermal performance of a solar assisted heat pump system with an energy storage. International Journal of Energy Research 2004, 28, 2, pp. 163 175. DOI: $10.1002 /$ er.959.

[6] Çomakly Ö., Bayramoğlu M., Kaygusuz K. A Thermodynamic model of a solar assisted heat pump system with energy storage. Solar Energy, 56, 6, 1996, 485-492. DOI:10.1016/0038092X(96)00005-9.

[7] Zalba B., Marìn J. M., Cabeza L.F., Mehling H. Review on thermal energy storage with phase change: materials, heat transfer analysis and applications. Applied Thermal Engineering 2003, 23, 251-283. doi:10.1016/S1359-4311(02)00192-8

[8] Fasulo A., Follari J., Barral J. Comparison between a simple collector accumulator and conventional accumulator. Solar Energy 2001, 71, 6 ,pp. 389-401. DOI:10.1016/S0038-092X(01)00077-9.

[9] Sozen A., Altiparmak D., Usta H. Development and testing of a prototype of absorption heat pump system operated by solar energy, Applied Thermal Engineering 2002, 22, 16 ,pp. 1847-1859. DOI:10.1016/S1359-4311(02)00109-6. 
[10] Ozgener O., Hepbasli A. Experimental performance analysis of a solar assisted ground-source heat pump greenhouse heating system. Energy and Buildings 2005, 37, 1, pp. 101-110. DOI:10.1016/j.enbuild.2004.06.003.

[11] Huang B.J., Lee C.P., Performance evaluation method of solar-assisted heat pump water heater. Applied Thermal Engineering 2007, 27, 568-575. doi:10.1016/j.applthermaleng.2006.06.005

[12] Dong X.D., Liu S., Asada H., Itoh H. Multivariable Control of Vapor Compression Systems. HVAC\&R Research 1998, 4, 3, pp. 205-230.

[13] Chaturvedi,D., Chen T., Kheireddine A. Thermal performance of a variable capacity direct expansion solar-assisted heat pump. Energy Conversion and Management 1998, 30 (3), pp. 181-191. DOI:10.1016/S0196-8904(96)00228-2.

[14] Huang, B.J., Lee, C.P. Long-term performance of solar-assisted heat pump water heater. Renewable Energy 2003, 29, pp. 633-639. DOI:10.1016/j.renene.2003.07.004.

[15] Huang B.J., Lee J.P., Chyng J.P. Heat-pipe enhanced solar-assisted heat pump water heater. Solar Energy 2005, 78, 3, pp. 375-381. DOI:10.1016/j.solener.2004.08.009.

[16] Gorozabel Chata F.B., Chaturvedi S.K., Almogbel A. Analysis of a direct expansion solar assisted heat pump using different refrigerants. Energy Conversion and Management 2005, 46, 2614-2624. DOI:10.1016/j.enconman.2004.12.001.

[17] Tagliafico L.A., Scarpa F., Senarega M. A compact dynamic model for vapor compression refrigerated systems. In: Proc. ESDA 2006, 8th Biennial ASME Conf. on Engineering Systems Design and Analysis, Torino, 2006.

[18] Lemmon E.W., Mc Linden M.O., Huber M.L. Standard Reference Database 23, Version 7.0. Physical and Chemical Properties Division. National Institute of Standard and Technology (NIST), (C) 2002 by the U.S. Secretary of Commerce.

[19] Danfoss. Compressor, Collection of Datasheets, Refrigeration and Air Conditioning. CK.50.B5.02, January 2002, pp. 62-63.

[20] Kalogirou S.A. Solar thermal collectors and applications. Progress in Energy and Combustion Science 2004, 30, pp. 231-295. DOI:10.1016/j.pecs.2004.02.001.

[21] The MathWorks, Inc, 2002. MATLAB®- The Language of Technical Computing, ver. 6.5 Release 13. Simulink®- Simulation and Model-Based Design. 
[22] DIAM (Dept. of ambient engineering), 2004.txt. http://www.dicat.unige.it/meteo/text_files/dati/ (07.26.2010). Univ. of Genoa, Italy.

[23] Anderson T.N., Morrison G.L. Effect of load pattern on solar-boosted heat pump water heater performance, Solar Energy 2007, 81, 11, pp. 1386-1395. DOI:10.1016/j.solener.2007.01.018.

[24] Moran M.J., Availability Analysis: A Guide to Efficient Energy Use. Prentice-Hall, 1982, ISBN $013054874 \mathrm{X} / 9780130548740$

[25] European Council Directive 92/42/EEC. The Boiler Efficiency Directive: Council Directive on Efficiency Requirements for New Hot-Water Boilers Fired with Liquid or Gaseous Fuels. Official Journal L 167, 22/06/1992, pp. 17 - 28.

[26]International Energy Agency. Energy Efficiency Indicators for Public Electricity Production from Fossil Fuels. IEA Information paper, In Support of the G8 Plan of Action. (C) OECD /IEA, 2008, p. 5. http://www.iea.org/textbase/Papers/2008/cd_energy_efficiency_policy/7-Energy\%20utilities/7En_Efficiency_Indicators.pdf (07.26.2010).

[27] Li Y.W., Wang R.Z., Wu J.Y., Xu Y.X. Experimental performance analysis on a direct-expansion solar-assisted heat pump water heater. Applied Thermal Engineering 2007, 27, 2858-2868, doi:10.1016/j.applthermaleng.2006.08.007.

[28] Aye Lu, Charters W.W.S., Chaichana C. Solar Heat Pumps Systems for Domestic Hot Water. Solar Energy 2002, 73, 3, pp. 169-175. DOI: 10.1016/S0038-092X(02)00043-9

[29] Huang B.J., Chyng J.P. Performance Characteristics of Integral Type Solar Assisted Heat Pumps. Solar Energy 2001, 71, 6, pp. 403-414. DOI:10.1016/S0038-092X(01)00076-7.

[30] Chyng J.P., Lee C.P., Huang B.J. Performance analysis of a solar-assisted heat pump water heater. Solar Energy 2003, 74 ,1 , pp. 33-44. DOI:10.1016/S0038-092X(03)00110-5.

[31] ISO 9459-3:1997(E). Performance test for Solar plus supplementary Systems. International Standards Organization, Geneva, Switzerland. 1997.

[32] Kulkarni G.K., Kedare S.B., Bandyopadhyay S. Determination of design space and optimization of solar water heating systems. Solar Energy 2007, 81, 8, pp. 958-96. doi:10.1016/j.solener.2006.12.003. 


\section{Appendix - Lumped dynamic model}

In this appendix, the simplified dynamic lumped model used to simulate the direct expansion solar assisted heat pump is synthesized.

\section{A.1 Main assumptions}

With reference to the plant sketch of Figure 2(A) and the corresponding thermodynamic cycle of the refrigerant fluid of Figure 2(B), a model is proposed to describe the dynamic behavior of the systems. Only the dynamics of the thermal inertias associated to the evaporator/panel, the condenser and storage tank will be described, while all the phenomena characterized by time constants smaller than few seconds will be systematically neglected.

In particular the following simplifying hypotheses were assumed:

- evaporation and condensation processes of the fluid are described only by means of steady-state first law balances;

- $\quad$ the refrigerant fluid temperature is assumed to be the same of that of the involved heat exchanger body (convective thermal resistances inside tubes have been neglected).

- the whole thermal capacity has been concentrated in the material of the heat exchangers,

- the expansion valve is simply described by its isenthalpic process,

- the dynamics of the reciprocating VCC system (conceived as a hermetic volumetric compressor operated by an asynchronous electrical motor) and of the associated regulation system (inverter) are not considered.

The performance of the refrigeration cycle is simulated by means of steady state, off-design calculations based on the thermodynamics of the refrigerant fluid, developed in a MATLAB Function code and coupled to a properly adapted NIST REFPROP database [18] for the calculation of the thermophysical properties.

\section{A.2 - Control volume balance equations}

The inlet-outlet energy balance equations, in steady state, for each component of the vapor-compression system turn out to be (kinetic and gravitational terms neglected as usual):

compressor

condenser

$$
\begin{aligned}
& P_{c}=\dot{m}_{r}\left(h_{2}-h_{1}\right) \\
& q_{\text {cond }}=\dot{m}_{r}\left(h_{2}-h_{3}\right)
\end{aligned}
$$


expansion valve

evaporator

$$
\begin{aligned}
& 0=\dot{m}_{r}\left(h_{3}-h_{4}\right) \\
& q_{\text {evap }}=\dot{m}_{r}\left(h_{1}-h_{4}\right)
\end{aligned}
$$

where $P_{\mathrm{c}}$ is the power (work) done on the refrigerant by the compressor, $q_{\mathrm{cond}}$ is the power (heat) discharged from the refrigerant to the warm region (the condenser inside the water tank) while $q_{\text {evap }}$ enters the refrigerant coming from the cold region (the evaporator). $\dot{m}_{r}$ is the refrigerant mass flow rate; $h_{1} h_{2} h_{3}$ and $h_{4}$ represent specific enthalpy values at the relevant points numbered in Figure 2(B).

To avoid misunderstanding, we have used a notation in which all the energy transfers (work and heat) are assumed to be positive in the direction suggested by the arrows.

\section{A.3 - Dynamic equations}

The differential transient equations of the condenser and the evaporator, together with the dynamics of the storage tank (fully mixed model), were described by means of lumped unsteady energy balance equations by neglecting, as said, the fluid-wall temperature gradient in respect to the wall-outside gradients $\left(T_{\text {cond }}\right.$ $\left.=T_{3}, T_{\text {evap }}=T_{1}\right)$ :

condenser

$$
(c M)_{\text {cond }} \frac{d T_{\text {cond }}}{d \tau}=q_{\text {cond }}-q_{\text {out }}
$$

evaporator/panel

$$
(c M)_{\text {evap }} \frac{d T_{\text {evap }}}{d \tau}=q_{\text {in }}-q_{\text {evap }}
$$

water tank

$$
(c M)_{s t g} \frac{d T_{s t g}}{d t}=q_{\text {out }}-q_{d}-q_{s t g}
$$

where the proper heat transfer equations are provided in then form

$$
q_{x}=(k A)_{a-b}\left(T_{a}-T_{b}\right) \quad \text { or } \quad q_{y}=\dot{m} c_{p}\left(T_{\text {out }}-T_{\text {in }}\right)
$$

\section{A.4 - Constitutive and other relations}

Finally, we make use of the analytical description of the fluid enthalpy in correspondence of the saturation lines (Eqs. A.8,A.9), of the relations for the calculation of the actual enthalpy at the compressor outlet (Eqs. A.10, A.11), and of the expression for the refrigerant mass flow rate (Eq. A.12).

$$
\begin{gathered}
h_{1}=h_{l}\left(T_{1}\right) \\
h_{3}=h_{v}\left(T_{3}\right) \\
h_{2 s}=f\left(T_{1}, T_{2}\right)
\end{gathered}
$$




$$
\begin{aligned}
& \eta_{c}=\frac{\left(h_{2 i d}-h_{1}\right)}{\left(h_{2}-h_{1}\right)} \\
& \dot{m}_{r}=\frac{\omega}{60} \frac{\eta_{v} V_{c}}{v\left(T_{1}\right)}
\end{aligned}
$$

Where $V_{C}$ is the compressor displacement. Isentropic, $\eta_{\mathrm{c}}$, and volumetric, $\eta_{\mathrm{v}}$, compressor efficiencies have been adapted from the performance map data of a major manufacturer [19], relative to the variable speed drive compressor TLV6K:

$$
\begin{aligned}
& \eta_{v}=0.932-0.087\left(\frac{\omega}{3000}\right)-0.0162\left(\frac{p_{2}}{p_{1}}\right) \\
& \eta_{c}=0.65-0.087\left(\frac{\omega}{3000}\right)+0.00285\left(\frac{p_{2}}{p_{1}}\right)-0.000415\left(\frac{p_{2}}{p_{1}}\right)^{2}
\end{aligned}
$$

The model, after a tuning stage, has been tested against an isahp prototype actually under construction at our department. These very preliminary tests, both static and dynamic, show a good agreement between simulated and measured behavior, although some differences are still present. 


\section{Tables}

Table 1. Main geometrical and thermal data of the heating systems. See the nomenclature section for the meaning of each symbol.

\begin{tabular}{|c|c|c|c|}
\hline & & ISAHP & TSP \\
\hline \multicolumn{4}{|c|}{ panel/evaporator } \\
\hline & $\mathrm{A}, \quad \mathrm{m}^{2}$ & 2 & 4 \\
\hline & $\mathrm{M}, \quad \mathrm{kg}$ & 18 & 80 \\
\hline & $\mathrm{KA}, \mathrm{WK}^{-1}$ & 30 & 35 \\
\hline & Mc, $\mathrm{JK}^{-1}$ & 16400 & 7200 \\
\hline & $\alpha$ & 0.93 & 0.81 \\
\hline & $\mathcal{E}$ & 0.4 & 0.1 \\
\hline \multirow[t]{5}{*}{ compressor } & & 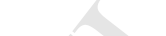 & ) \\
\hline & Vcc, $\mathrm{cm}^{3}$ & 5.7 & - \\
\hline & $\omega, \quad \mathrm{rpm}$ & $1600-4500$ & - \\
\hline & $\eta_{\mathrm{v}}$ & Eq. A13 & - \\
\hline & $\eta_{c}$ & Eq. A14 & - \\
\hline \multicolumn{4}{|l|}{$\begin{array}{l}\text { storage heat } \\
\text { exchanger }\end{array}$} \\
\hline & Mc, $\mathrm{JK}^{-1}$ & 2000 & 2000 \\
\hline & $\mathrm{KA}, \mathrm{WK}^{-1}$ & 100 & 50 \\
\hline \multicolumn{4}{|l|}{ storage tank } \\
\hline & $\mathrm{M}, \mathrm{kg}$ & 300 & 300 \\
\hline & $\mathrm{K}, \mathrm{Wm}^{-1} \mathrm{~K}^{-1}$ & 0.06 & 0.06 \\
\hline & $\mathrm{S}, \quad \mathrm{m}$ & 0.05 & 0.05 \\
\hline
\end{tabular}


Table 2. Performance comparison results. Four representative months. The behavior of the $2 \mathrm{~m}^{2}$ innovative panel ISAHP is reported side by side with that of a $4 \mathrm{~m}^{2}$ traditional thermal panel. All data are averaged over 100 different simulations. When applicable, the confidence associated to these results is reported in brackets (as 95\% confidence bounds).

\begin{tabular}{|c|c|c|c|c|c|c|c|c|}
\hline & \multicolumn{2}{|c|}{ January } & \multicolumn{2}{|c|}{ April } & \multicolumn{2}{|c|}{ July } & \multicolumn{2}{|c|}{ October } \\
\hline $\begin{array}{l}T_{\mathrm{e}}, \quad \text { ext temp } \\
\end{array}$ & \multicolumn{2}{|c|}{7.1} & \multicolumn{2}{|c|}{13.2} & \multicolumn{2}{|c|}{23.7} & \multicolumn{2}{|c|}{17.6} \\
\hline$T_{\text {tap }}$, cold water temp, $\quad{ }^{\circ} \mathrm{C}$ & \multicolumn{2}{|c|}{12} & \multicolumn{2}{|c|}{13} & \multicolumn{2}{|c|}{15} & \multicolumn{2}{|c|}{14} \\
\hline$T_{\text {int }}$, internal room temp, ${ }^{\circ} \mathrm{C}$ & \multicolumn{2}{|c|}{20} & \multicolumn{2}{|c|}{22} & \multicolumn{2}{|c|}{26} & \multicolumn{2}{|c|}{23} \\
\hline$E_{\mathrm{s}}, \quad$ solar energy, $\mathrm{MJ} \mathrm{m}^{-2}$ day $^{-1}$ & \multicolumn{2}{|c|}{7.7} & \multicolumn{2}{|c|}{20.4} & \multicolumn{2}{|c|}{27.5} & \multicolumn{2}{|c|}{10.0} \\
\hline$E_{\text {user }}$, used energy, $\quad$ MJ & \multicolumn{2}{|c|}{$\begin{array}{l}1097 \\
(17)\end{array}$} & \multicolumn{2}{|c|}{$\begin{array}{c}1032 \\
(17)\end{array}$} & \multicolumn{2}{|c|}{$\begin{array}{l}992 \\
(16)\end{array}$} & \multicolumn{2}{|c|}{$\begin{array}{l}1000 \\
(17)\end{array}$} \\
\hline \multirow[t]{2}{*}{$G_{\mathrm{w}}$, daily water demand, lday $^{-1}$} & \multicolumn{2}{|c|}{$\begin{array}{l}265 \\
(4)\end{array}$} & \multicolumn{2}{|c|}{$\begin{array}{l}257 \\
(4)\end{array}$} & & $\begin{array}{l}63 \\
4) \\
\end{array}$ & \multicolumn{2}{|c|}{ (4) } \\
\hline & ISAHP & TSP & ISAHP & TSP & ISAHP & TSP & ISAHP & TSP \\
\hline$\left[{ }^{\circ} \mathrm{C}\right]$ & $\begin{array}{c}7.7 \\
(0.02)\end{array}$ & $\begin{array}{c}13.0 \\
(0.02)\end{array}$ & $\begin{array}{l}17.0 \\
(0.3)\end{array}$ & $\begin{array}{c}28.0 \\
(0.04)\end{array}$ & $\begin{array}{c}29.6 \\
(0.07)\end{array}$ & $\begin{array}{c}43.0 \\
(0.07)\end{array}$ & $\begin{array}{c}17.5 \\
(0.06)\end{array}$ & $\begin{array}{c}24.3 \\
(0.02)\end{array}$ \\
\hline$T_{p a n}(\mathrm{HP} / \mathrm{TSP} \mathrm{ON})\left[{ }^{\circ} \mathrm{C}\right]$ & $\begin{array}{c}10.4 \\
(0.05)\end{array}$ & $\begin{array}{c}31.3 \\
(0.14)\end{array}$ & $\begin{array}{c}21.7 \\
(0.08)\end{array}$ & $\begin{array}{c}55.6 \\
(0.27)\end{array}$ & $\begin{array}{c}34.7 \\
(0.28)\end{array}$ & $\begin{array}{c}65.6 \\
(0.27)\end{array}$ & $\begin{array}{c}18.2 \\
(0.26)\end{array}$ & $\begin{array}{l}38.5 \\
(0.3)\end{array}$ \\
\hline$\left[{ }^{\circ} \mathrm{C}\right]$ & $\begin{array}{c}24.7 \\
(0.15)\end{array}$ & $\begin{array}{c}19.3 \\
(0.08)\end{array}$ & $\begin{array}{c}39.1 \\
(0.25)\end{array}$ & $\begin{array}{l}32.1 \\
(0.2)\end{array}$ & $\begin{array}{l}50.4 \\
(0.4)\end{array}$ & $\begin{array}{l}42.7 \\
(0.3)\end{array}$ & $\begin{array}{l}32.9 \\
(0.3)\end{array}$ & $\begin{array}{l}25.2 \\
(0.1)\end{array}$ \\
\hline$T_{s t g}(\mathrm{HP} / \mathrm{TSP} \mathrm{ON})\left[{ }^{\circ} \mathrm{C}\right]$ & $\begin{array}{l}26.1 \\
(0.2)\end{array}$ & $\begin{array}{l}20.2 \\
(0.1)\end{array}$ & $\begin{array}{c}40.4 \\
(0.24)\end{array}$ & $\begin{array}{l}34.2 \\
(0.2)\end{array}$ & $\begin{array}{l}51.4 \\
(0.5)\end{array}$ & $\begin{array}{l}43.8 \\
(0.2)\end{array}$ & $\begin{array}{l}34.5 \\
(0.5)\end{array}$ & $\begin{array}{l}26.3 \\
(0.2)\end{array}$ \\
\hline$E_{\text {gas burner }}$ & $\begin{array}{l}698 \\
(17)\end{array}$ & $\begin{array}{l}866 \\
(17)\end{array}$ & $\begin{array}{l}265 \\
(12)\end{array}$ & $\begin{array}{l}446 \\
(13)\end{array}$ & $\begin{array}{c}72.8 \\
(5)\end{array}$ & $\begin{array}{l}180 \\
(9)\end{array}$ & $\begin{array}{l}422 \\
(13)\end{array}$ & $\begin{array}{l}653 \\
(14)\end{array}$ \\
\hline$C O P_{H P}$ & $\begin{array}{c}8.1 \\
(0.03)\end{array}$ & - & $\begin{array}{c}7.9 \\
(0.05)\end{array}$ & - & $\begin{array}{c}8.9 \\
(0.07)\end{array}$ & - & $\begin{array}{c}8.1 \\
(0.1)\end{array}$ & - \\
\hline$\eta_{I I}$ & $\begin{array}{c}0.35 \\
\left(3 \cdot 10^{-3}\right)\end{array}$ & & $\begin{array}{c}0.32 \\
\left(4 \cdot 10^{-3}\right)\end{array}$ & - & $\begin{array}{c}0.31 \\
(0.014)\end{array}$ & - & $\begin{array}{c}0.34 \\
\left(7 \cdot 10^{-3}\right)\end{array}$ & - \\
\hline$\eta_{E x}$ & $\begin{array}{c}0.36 \\
\left(3 \cdot 10^{-3}\right)\end{array}$ & & $\begin{array}{c}0.35 \\
\left(4 \cdot 10^{-3}\right)\end{array}$ & - & $\begin{array}{c}0.34 \\
(0.015)\end{array}$ & - & $\begin{array}{c}0.36 \\
\left(5 \cdot 10^{-3}\right)\end{array}$ & - \\
\hline$\eta_{p a n}$ & $\begin{array}{c}0.84 \\
\left(2 \cdot 10^{-3}\right)\end{array}$ & $\begin{array}{c}0.31 \\
\left(5 \cdot 10^{-2}\right)\end{array}$ & $\begin{array}{c}0.63 \\
\left(3 \cdot 10^{-3}\right)\end{array}$ & $\begin{array}{c}0.31 \\
\left(5 \cdot 10^{-2}\right)\end{array}$ & $\begin{array}{c}0.58 \\
\left(5 \cdot 10^{-3}\right)\end{array}$ & $\begin{array}{c}0.31 \\
\left(5 \cdot 10^{-2}\right)\end{array}$ & $\begin{array}{c}0.91 \\
\left(1 \cdot 10^{-3}\right)\end{array}$ & $\begin{array}{c}0.31 \\
\left(5 \cdot 10^{-2}\right)\end{array}$ \\
\hline$\xi_{\text {free }}$ & $\begin{array}{c}0.31 \\
\left(5 \cdot 10^{-3}\right)\end{array}$ & $\begin{array}{c}0.21 \\
\left(3 \cdot 10^{-3}\right)\end{array}$ & $\begin{array}{c}0.64 \\
(0.011)\end{array}$ & $\begin{array}{c}0.56 \\
\left(1 \cdot 10^{-2}\right)\end{array}$ & $\begin{array}{c}0.8 \\
(0.016)\end{array}$ & $\begin{array}{c}0.81 \\
(0.016)\end{array}$ & $\begin{array}{c}0.5 \\
\left(1 \cdot 10^{-2}\right)\end{array}$ & $\begin{array}{c}0.34 \\
(0.007)\end{array}$ \\
\hline$\xi_{\text {spe }}$ & $\begin{array}{c}0.25 \\
\left(6 \cdot 10^{-3}\right)\end{array}$ & $\begin{array}{c}0.21 \\
\left(5 \cdot 10^{-3}\right)\end{array}$ & $\begin{array}{c}0.48 \\
(0.014)\end{array}$ & $\begin{array}{c}0.56 \\
(0.019)\end{array}$ & $\begin{array}{c}0.63 \\
(0.024)\end{array}$ & $\begin{array}{c}0.81 \\
(0.043)\end{array}$ & $\begin{array}{c}0.39 \\
\left(1 \cdot 10^{-2}\right)\end{array}$ & $\begin{array}{c}0.34 \\
\left(1 \cdot 10^{-2}\right)\end{array}$ \\
\hline$\xi_{\text {comp }}$ & $\begin{array}{c}0.05 \\
\left(1 \cdot 10^{-3}\right)\end{array}$ & - & $\begin{array}{c}0.10 \\
\left(1 \cdot 10^{-3}\right)\end{array}$ & - & $\begin{array}{c}0.12 \\
\left(1 \cdot 10^{-3}\right)\end{array}$ & - & $\begin{array}{c}0.08 \\
\left(1 \cdot 10^{-3}\right)\end{array}$ & - \\
\hline (HP ON) & 3650 & - & 3000 & - & 2300 & - & 3050 & - \\
\hline
\end{tabular}


Table 3. Performance comparison of the results obtained with different thermal load simulation methods. Free used energy fraction, $\xi_{\text {free }}$ and saved primary energy index, $\xi_{\text {spe }}$. User load has been simulated by means of a duty cycle (duty) rather then using a stochastic process (RND) as in table 2. $\mathrm{G}_{\mathrm{w}}=2531$ day $^{-1}$.

\begin{tabular}{|c|c|c|c|c|c|c|c|c|c|c|c|}
\hline & & \multicolumn{2}{|c|}{ January } & \multicolumn{2}{|c|}{ April } & \multicolumn{2}{|c|}{ July } & \multicolumn{2}{|c|}{ October } & \multicolumn{2}{|c|}{ Year 04} \\
\hline & & ISAHP & TSP & ISAHP & TSP & ISAHP & TSP & ISAHP & TSP & ISAHP & TSP \\
\hline \multirow{2}{*}{$\xi_{\text {free }}$} & RND & 0.31 & 0.21 & 0.64 & 0.56 & 0.80 & 0.81 & 0.50 & 0.34 & 0.56 & 0.48 \\
\hline & duty & 0.34 & 0.22 & 0.67 & 0.60 & 0.85 & 0.88 & 0.53 & 0.36 & 0.60 & 0.51 \\
\hline \multirow{2}{*}{$\xi_{s p e}$} & RND & 0.25 & 0.21 & 0.48 & 0.56 & 0.63 & 0.81 & 0.39 & 0.34 & 0.44 & 0.48 \\
\hline & duty & 0.27 & 0.22 & 0.52 & 0.59 & 0.68 & 0.88 & 0.41 & 0.36 & 0.47 & 0.51 \\
\hline
\end{tabular}




\section{Figure Captions}

Figure 1. Simplified schematic of a solar panel assembly together with auxiliary means. (A) TSP Traditional; (B) ISAHP device - the water loop has been replaced by a refrigerant vapor compression system.

Figure 2. Block diagram of the ISAHP device. Thermal transfers in evidence.

Figure 3. Genoa (Italy) October 2004, raw data. Environmental temperature (A) and solar irradiation (B).

Figure 4. Saved primary energy index, $\xi_{\text {spe }}$, as a function of the COP for the four representative months.

Figure 5. Instantaneous collector efficiency, $\eta_{p a n}$, values during an arbitrary July day. Dots represent the calculated data for ISAHP and TSP devices on the basis of simulation results. Dashed lines refer to literature data [20], respectively for bare panels and for single-glazed panels.

Figure 6. Synthetic view of two main figures of merit from table 2 ; Free used energy fraction, $\xi_{\text {free }}$ (left) and Saved primary energy index, $\xi_{\text {spe }}$. 
Figures

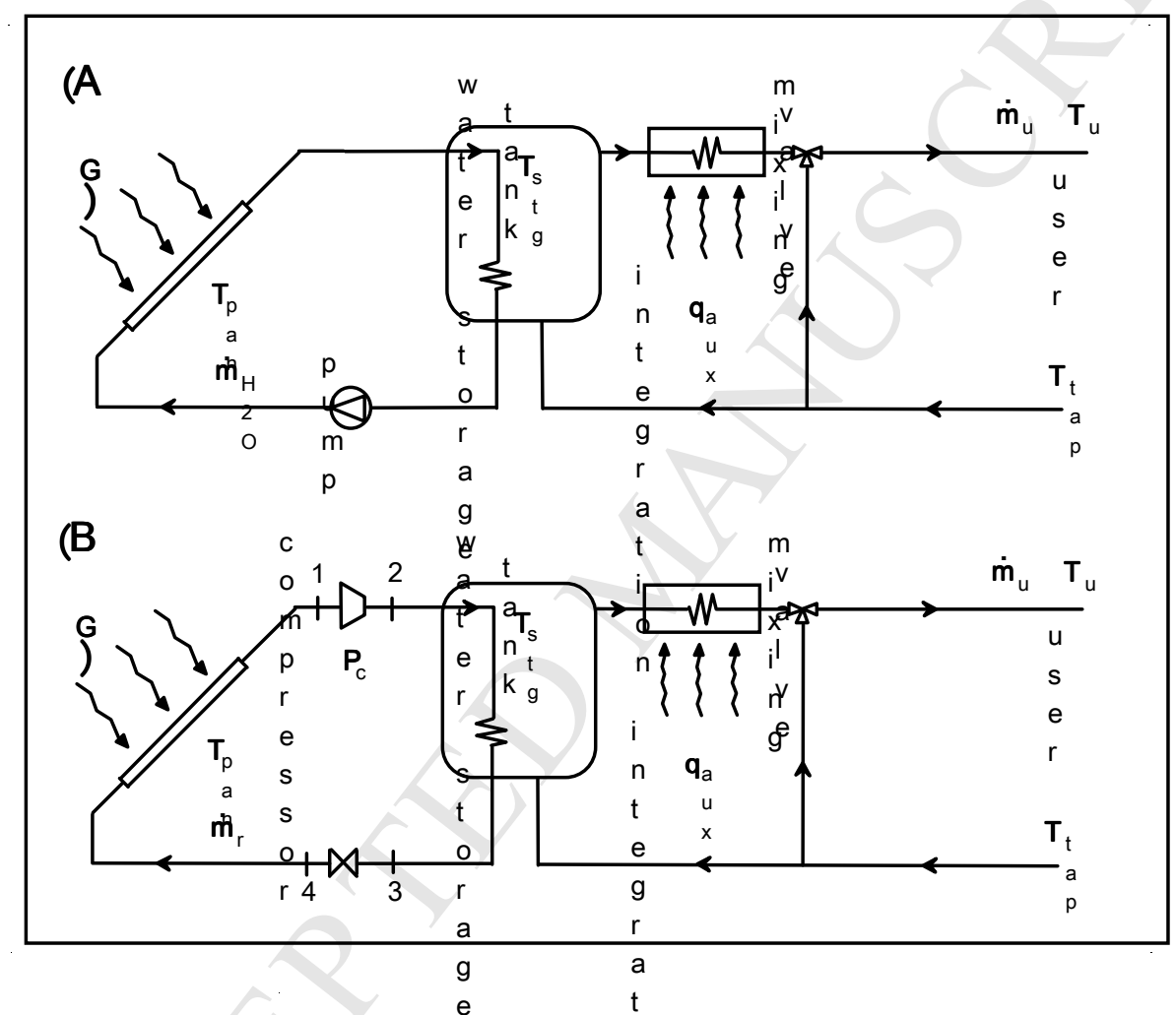

Figure 1. Simplified schematic of a solar panel assembly together with auxiliary means. (A) TSP - Traditional; (B) ISAHP device - the water loop has been replaced by a ræfrigerant vapor compression system. 


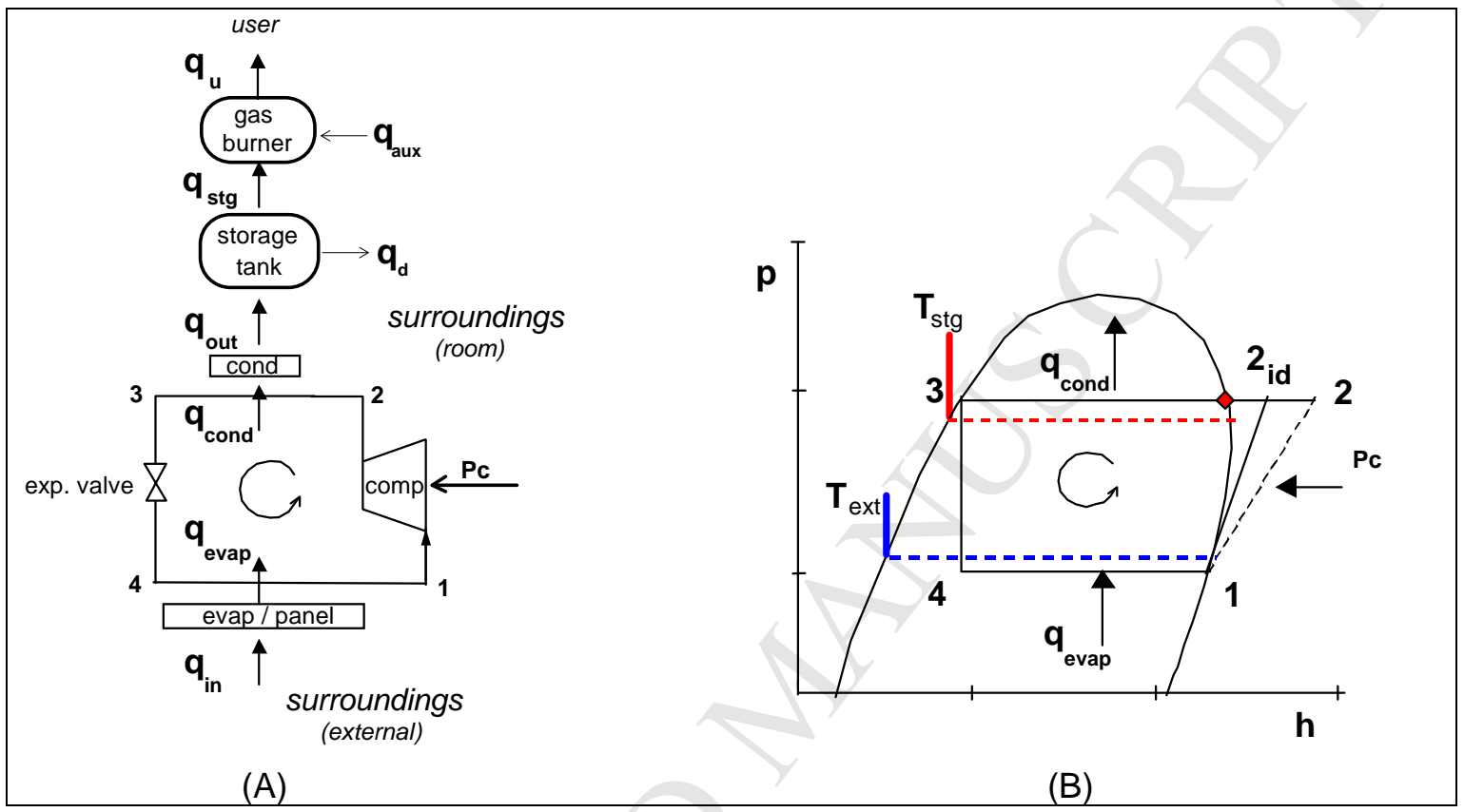

Figure 2. Block diagram of the ISAHP device with thermal transfers in evidence (A). Thermodynamic cycle in the enthalpy-pressure plane, no pressure losses (B). 


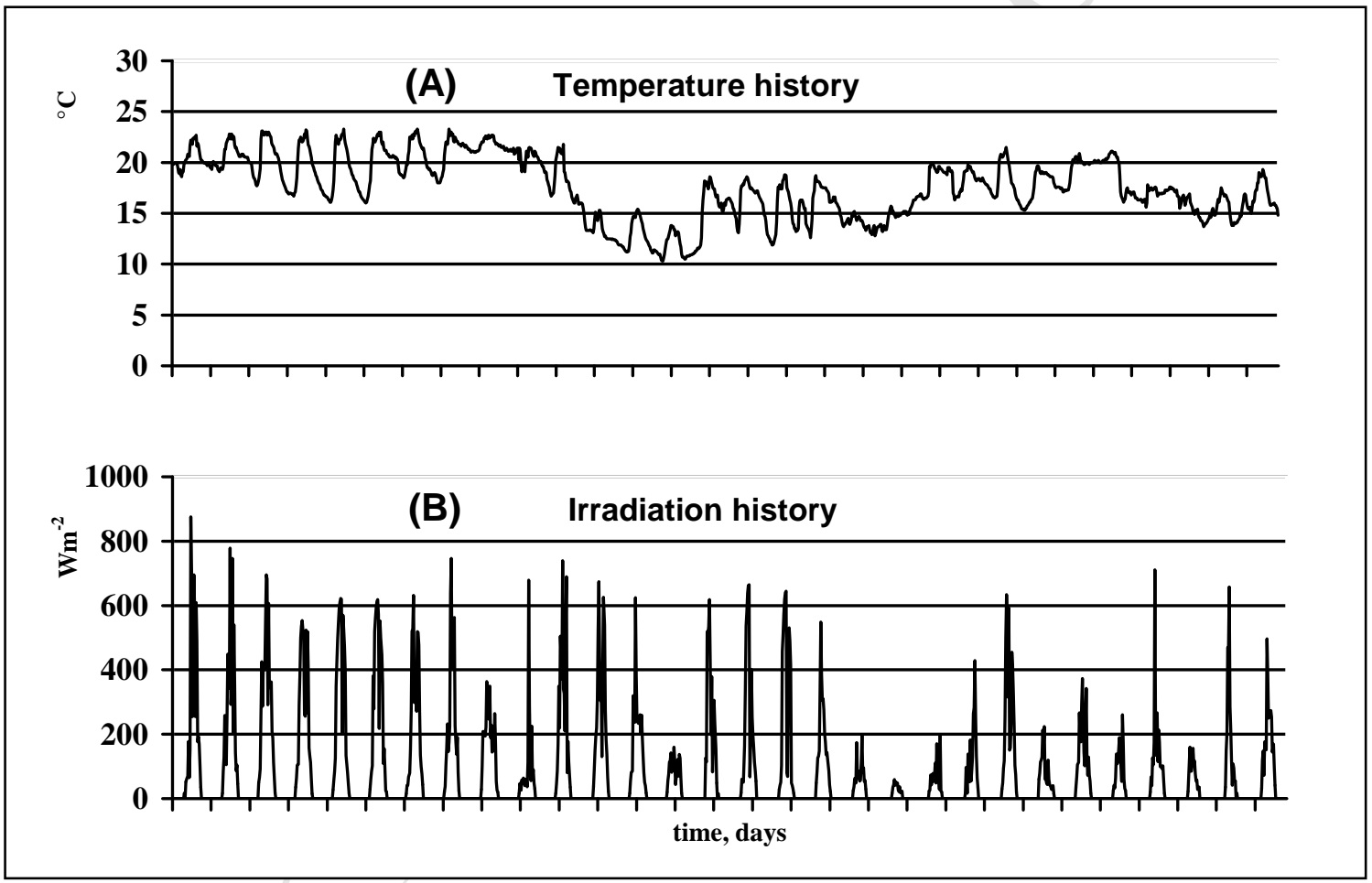

Figure 3. Genoa (Italy) October 2004 row data. Environmental temperature (A) and solar irradiation (B). 


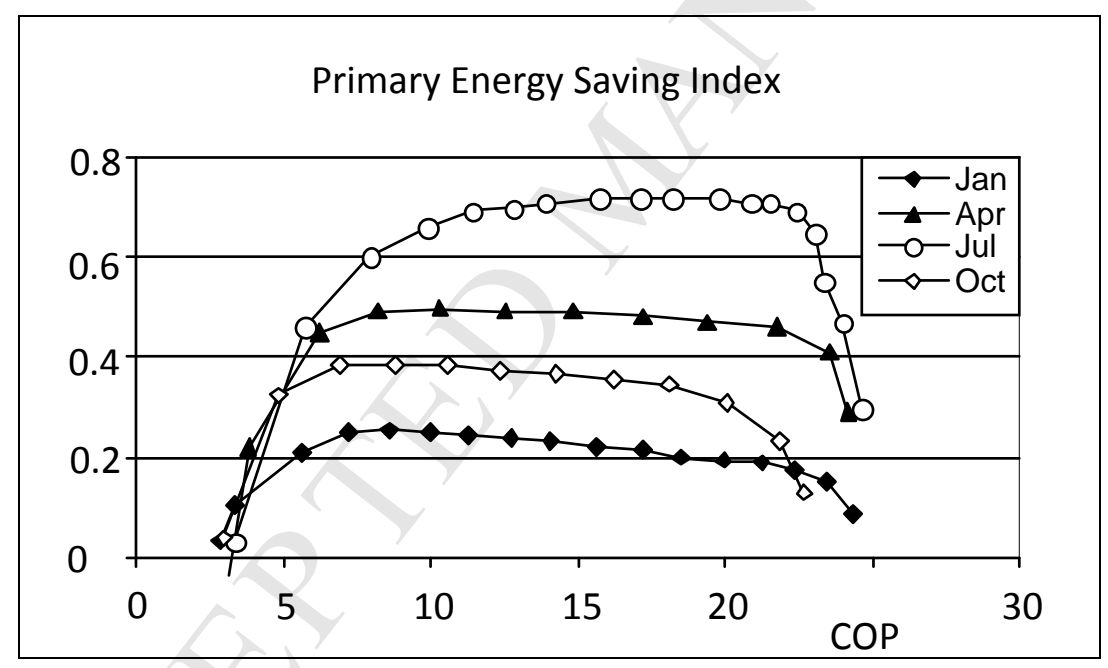

Figure 4. Saved primary energy index, $\xi_{s p e}$, as a function of the COP for the four representative months. 


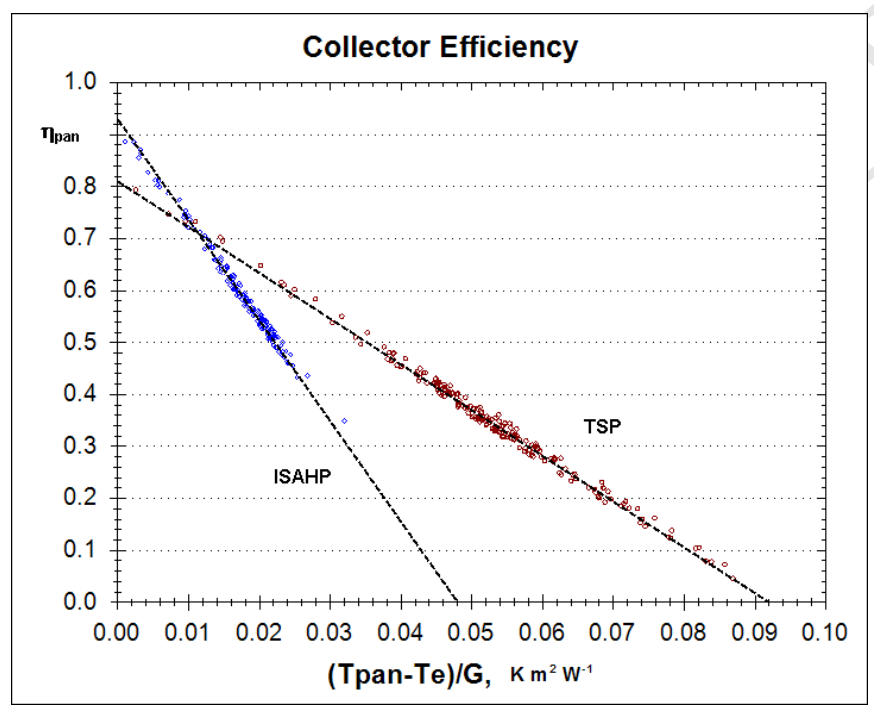

Figure 5. Instantaneous collector efficiency, $\eta_{p a n}$, values during an arbitrary July day. Dots represent the calculated data for ISAHP and TSP devices on the basis of simulation results. Dashed lines refer to literature data [20], respectively for bare panels and for single-glazed panels. 


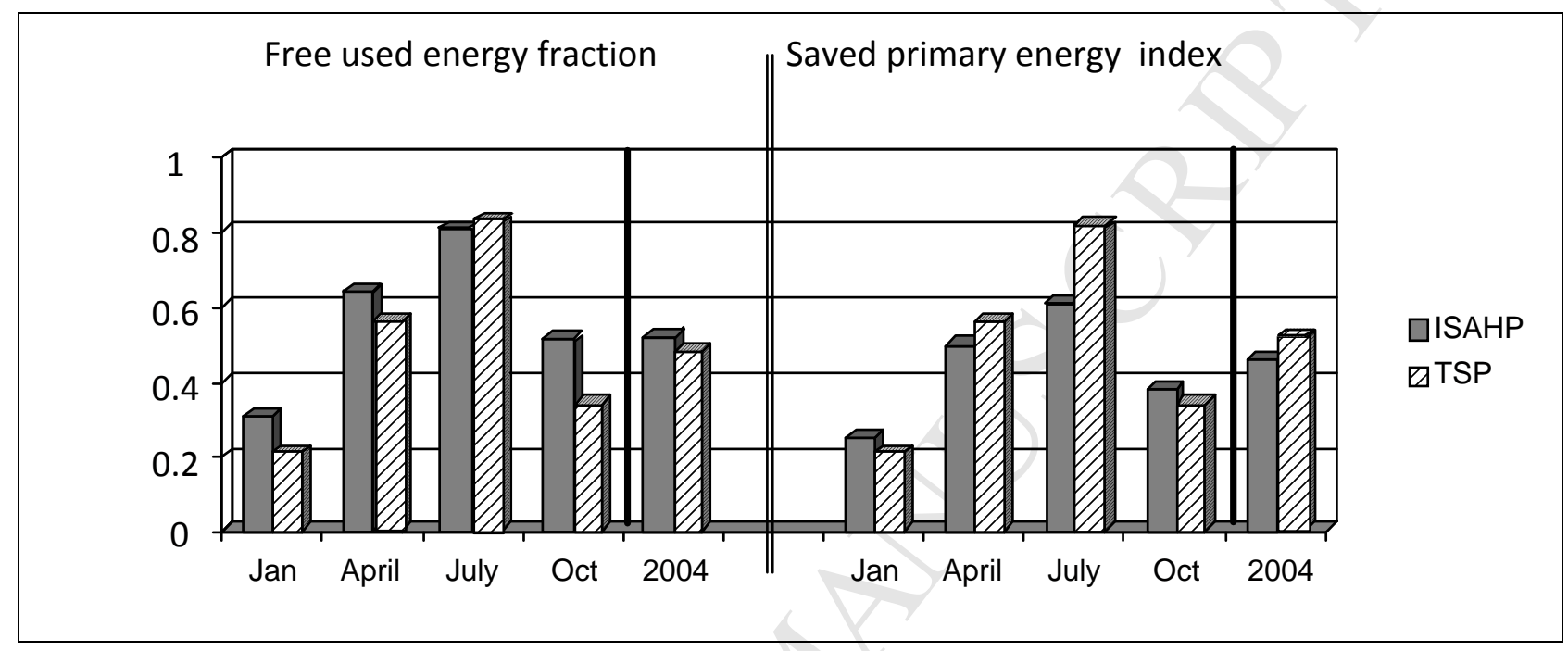

Figure 6. Synthetic view of two main figures of merit from table 2; Free used energy fraction, $\xi_{\text {free }}$ (left) and Saved primary energy index, $\xi_{\text {spe }}$ 


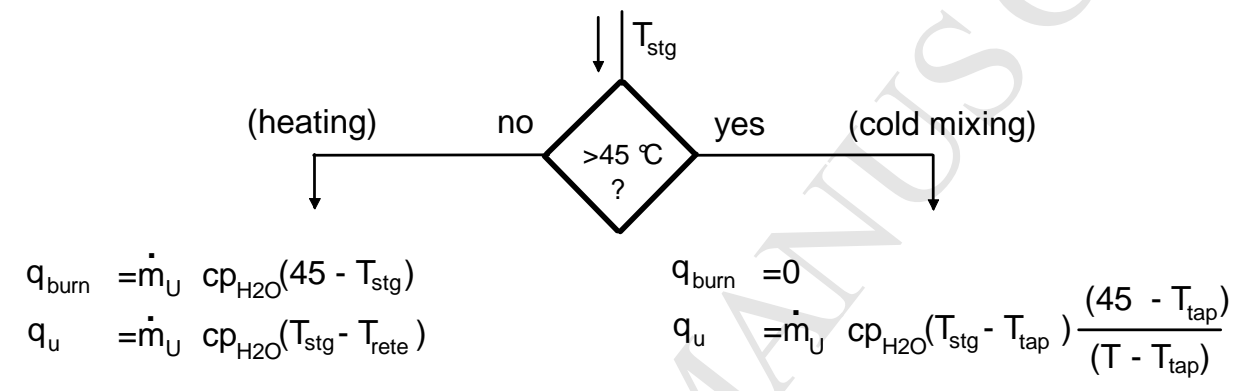

Figure A1. Diagram of the heating/mixing logic and associated expressions for the involved heat exchanges 


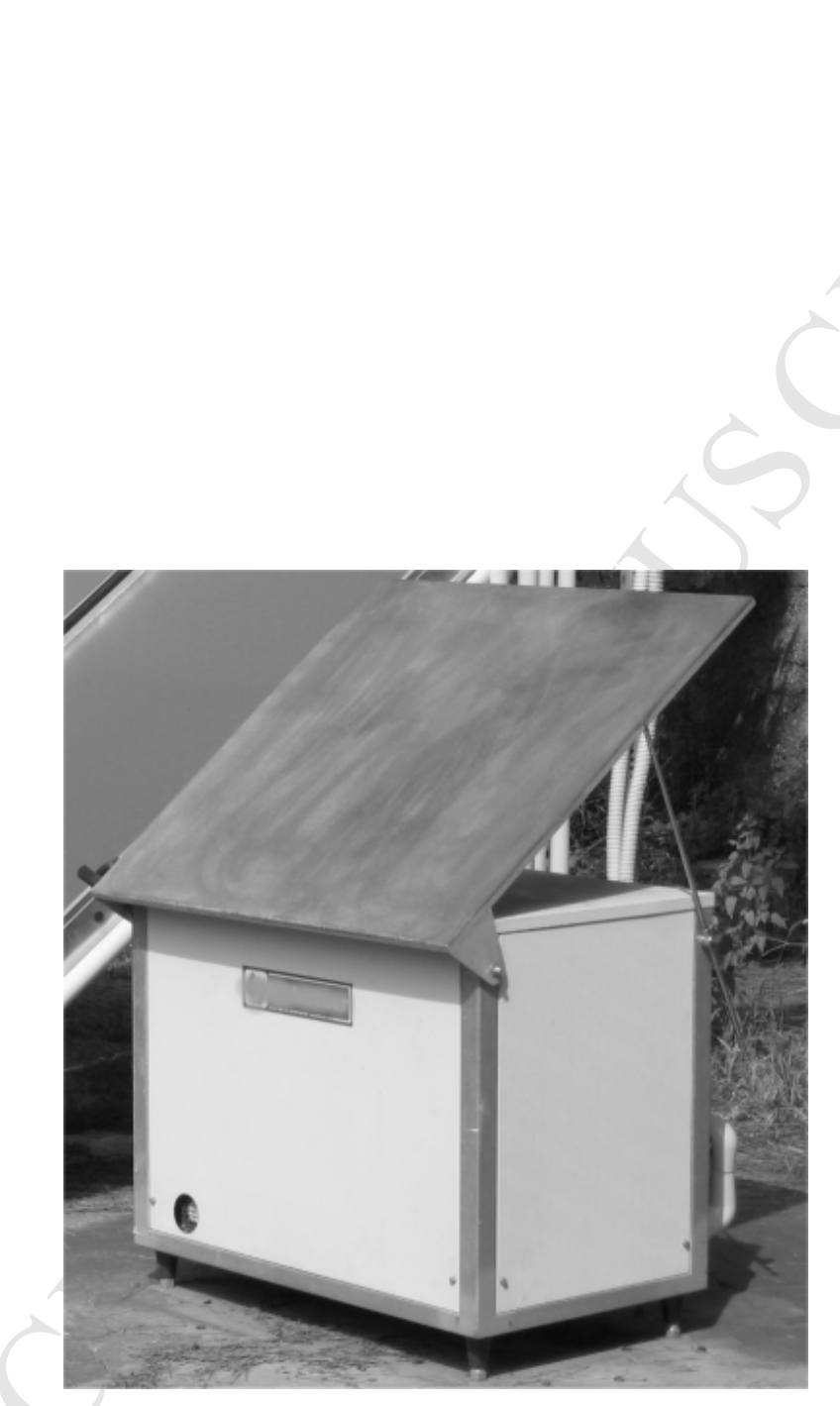

Figure A2. ISAHP prototype under construction at the Thermal Energy and Environmental Conditioning division of our department. 